\title{
症例報告
}

\author{
急速に進行した強皮症合併肺動脈性肺高血圧症の一例 \\ 石田素子，宮村 知也，海江田智絵，木 村大 作，中 村彰 宏 \\ 高濱宗一郎，喜 安純一，南＼cjkstart留美，山本政弘，末 松 栄一
}

\section{Rapidly progressive pulmonary arterial hypertension associated with systemic sclerosis : a case report}

\author{
Motoko IshidA, Tomoya Miyamura, Tomoe KaIedA, Daisaku Kimura, Akihiro Nakamura, \\ Soichiro TAKahama, Junichi Kiyasu, Rumi Minami, Masahiro Yamamoto and Eiichi Suematsu \\ Department of Internal Medicine and Rheumatology, Clinical Research Institute, National Hospital Organization, \\ Kyushu Medical Center
}

(Accepted February 7, 2013)

summary

\begin{abstract}
A 68-year-old female who had Raynaud phenomenon for a decade was admitted to our hospital in January 2012. She complained of sclerodactyly and scleroderma that did not extend past the elbows. She also had fingertip ulcers that repeatedly disappeared and recurred for several years. Blood tests showed that she was anti-centromere antibody positive. Therefore, she was diagnosed with limited cutaneous systemic sclerosis. Two months after diagnosis, she returned to our hospital because she experienced dyspnea on exertion and exacerbation of her fingertip ulcers. Chest X-rays revealed cardiac enlargement, an echocardiography showed tricuspid regurgitation with an increased tricuspid pressure gradient $(91 \mathrm{mmHg})$ and right heart catheterization showed a mean pulmonary arterial pressure of $59 \mathrm{mmHg}$. Chest computed tomography and lung perfusion scintigraphy showed no abnormalities. She was then diagnosed with pulmonary arterial hypertension associated with systemic sclerosis. She improved rapidly with daily treatments of prednisolone in addition to warfarin, bosentan and beraprost sodium. This is a rare case of rapidly progressive pulmonary arterial hypertension associated with systemic sclerosis that can be markedly improved with early diagnosis and treatment.
\end{abstract}

Key words_ _ pulmonary arterial hypertension; systemic sclerosis

抄 録

症例は 68 歳女性. 平成 10 年頃から Raynaud 症状，平成 20 年頃より指尖部潰瘍が出現し，増悪消退を繰り返し ていた。平成 24 年 1 月当院初診し，強指症状，両肘を超えない皮膚硬化，短指症，抗 centromere 抗体陽性で強皮 症（limited cutaneous systemic sclerosis ; lcSSc） と診断された。診断 2 か月後より労作時呼吸困難感を自覚，指尖 部潰瘍の増悪を認めた。心蔵超音波検査で推定肺動脈圧 $91 \mathrm{mmHg}$ を認めた。胸部レントゲンで心拡大を認める が，肺野異常なく，心機能正常，胸部 CT 検査・肺血流シンチで異常を認めず，右心カテーテル検査で平均肺動脈 圧 $59 \mathrm{mmHg}$ を確認し, 強皮症に伴う肺動脈性肺高血圧症と診断した。ボセンタン・ベラプロストナトリウム・ ワーファリンに加え，プレドニゾロンで治療を開始，臨床症状・検査所見は速やかに改善した。皮膚硬化進行や他 の臓器病変の出現は認めないものの強皮症関連肺動脈性肺高血圧症が急速に進行し，治療に速やかに反応した非常 に稀な症例を経験した. 


\section{はじめに}

強皮症（systemic sclerosis；SSc）に伴う肺動脈性 肺高血圧症 (pulmonary arterial hypertension ; PAH) は長い罹患期間後に慢性に発症することが多い。近 年, 肺高血圧症（pulmonary hypertension；PH）は 治療薬の進歩により生存率の改善が認められている ものの, SSc 関連のPAH の予後は未だ不良であ る. 今回我々は, 皮膚や他の臓器病変の変化は認め ないものの 2 か月で急速に進行した SSc 合併 PAH でステロイドを含む多剤併用治療により速やかな改 善を認めた症例を経験したので報告する.

\section{症例}

患 者 : 68 歳, 女性

主 訴: 体動時の呼吸苦

既往歴 : 高血圧症

家族歴 : 特記事項なし

現病歴: 平成 10 年頃より Raynaud 症状を自覚. 平成 20 年頃より指尖部潰瘍が出現し, 増悪寬解を 繰り返していた。平成 23 年 11 月より右母趾尖端潰 瘍が出現し, 平成 24 年 1 月 31 日当院紹介初診. 強 指症状, 両肘を超えない皮膚硬化, 短指症, 抗 centromere 抗体陽性で強皮症（limited cutaneous systemic sclerosis ; lcSSc) と診断した。診断時に施 行した心臓超音波検査では PH を疑う所見は認め なかった. 3 月下旬より労作時呼吸困難感を自覚,
4 月 10 日心蔵超音波検査で三尖弁圧較差 $91 \mathrm{mmHg}$ と上昇あり, 精査のため入院となった.

入院時現症: 身長 $145 \mathrm{~cm}$, 体重 $38.3 \mathrm{~kg}$, 体温 $36.9^{\circ} \mathrm{C}$, 脈拍数 $110 /$ 分 - 整, 血圧 $155 / 66 \mathrm{mmHg}$, 呼吸回数 20 回/分, $\mathrm{SpO} 293 \%$. 舌小帯の短縮あ り, 胸部呼吸音左右差なし, ラ音なし，心音 II 音 元進あり, Raynaud 症状あり, 右示指中指短指症 あり, Nail fold capillary change (NFCC) あり，右 母趾に既存の潰瘍あり，右足外側に新規潰瘍あり， 足背動脈触知不良, 顔面 - 前胸部中心に毛細血管拡 張あり, modified Rodnan total skin thickness score 16 点.

入院時検査所見（表 1）：検尿異常なし，血算異 常なし, 血液生化学では BNP $87.5 \mathrm{pg} / \mathrm{ml}$, NTproBNP $1012 \mathrm{pg} / \mathrm{ml}$ と著明な上昇を認め, 赤沈 は $31 \mathrm{~mm} / 1$ 時間值とやや交進していた。凝固線溶 系マーカーは正常であった，血液動脈ガス分析では 酸素分圧 $\mathrm{PaO} 271.1 \mathrm{mmHg}$ と低下を認めた。免疫 学的検査では CRP $1.29 \mathrm{mg} / \mathrm{dl}$ とやや上昇し, 抗核 抗体 1280 倍 (discrete-speckled pattern), 抗 centromere 抗体 182 と陽性, 抗 dsDNA 抗体, 抗 U1RNP 抗体, 抗リン脂質抗体はいずれも陰性であっ た.胸部 X 線検査ではうっ血像はないが，心拡大 （CTR 57\%）を認めた。 また，強皮症診断時には異 常所見を認めなかった心臓超音波検査では, 三尖弁 逆流が出現して抢り，三尖弁圧較差 $79 \mathrm{mmHg}$ と著 明な上昇を認め, 右心系の拡大と压排による心室中

表 1 入院時検査成績

\begin{tabular}{|c|c|c|c|c|c|}
\hline \multicolumn{2}{|c|}{$\langle$ urinalysis〉 } & \multicolumn{2}{|c|}{$\langle$ serum chemistry $\rangle$} & \multicolumn{2}{|c|}{$\langle\mathrm{ABG}\rangle$ room air } \\
\hline Prot & $(-)$ & $\mathrm{TP}$ & $7.1 \mathrm{~g} / \mathrm{dl}$ & $\mathrm{PH}$ & 7.438 \\
\hline OB & $(-)$ & $\mathrm{Alb}$ & $4.5 \mathrm{~g} / \mathrm{dl}$ & $\mathrm{PaCO} 2$ & $29.7 \mathrm{mmHg}$ \\
\hline sugar & $(-)$ & T.Bil & $0.6 \mathrm{mg} / \mathrm{dl}$ & $\mathrm{PaO} 2$ & $71.7 \mathrm{mmHg}$ \\
\hline$\langle\mathrm{CBC}\rangle$ & & $\mathrm{LDH}$ & $262 \mathrm{IU} / 1$ & HCO3- & $19.8 \mathrm{mmol} / 1$ \\
\hline WBC & $5800 / \mu \mathrm{l}$ & AST & $38 \mathrm{IU} / 1$ & \multicolumn{2}{|c|}{$\langle$ serology and immunology $\rangle$} \\
\hline Neut & $77 \%$ & ALT & $23 \mathrm{IU} / 1$ & CRP & $1.29 \mathrm{mg} / \mathrm{dl}$ \\
\hline Ly & $19 \%$ & BUN & $19 \mathrm{mg} / \mathrm{dl}$ & $\mathrm{IgG}$ & $876 \mathrm{mg} / \mathrm{dl}$ \\
\hline Mono & $4 \%$ & $\mathrm{Cr}$ & $0.7 \mathrm{mg} / \mathrm{dl}$ & $\mathrm{CH} 50$ & $45 \mathrm{U} / \mathrm{ml}$ \\
\hline $\mathrm{RBC}$ & $439 \times 10^{4} / \mu \mathrm{l}$ & $\mathrm{Na}$ & $141 \mathrm{mEq} / 1$ & ANA & $1280 \times$, Dis \\
\hline $\mathrm{Hb}$ & $13.5 \mathrm{~g} / \mathrm{dl}$ & $\mathrm{K}$ & $4.7 \mathrm{mEq} / 1$ & Anti-dsDNA Ab & $<12 \mathrm{U} / \mathrm{ml}$ \\
\hline $\mathrm{Ht}$ & $41.2 \%$ & $\mathrm{Cl}$ & $106 \mathrm{mEq} / 1$ & Anti-U1RNP Ab & $<5 \mathrm{IU} / \mathrm{ml}$ \\
\hline Plt & $24.7 \times 10^{4} / \mu \mathrm{l}$ & Glu & $84 \mathrm{mg} / \mathrm{dl}$ & Anti-Scl-70Ab & $12.9 \mathrm{U} / \mathrm{ml}$ \\
\hline \multirow{5}{*}{$\langle\mathrm{ESR}\rangle$} & $31 \mathrm{~mm} / \mathrm{hr}$ & BNP & $87.5 \mathrm{pg} / \mathrm{ml}$ & Anti-centromere $\mathrm{Ab}$ & 182 \\
\hline & & NTproBNP & $1012 \mathrm{pg} / \mathrm{ml}$ & PR3-ANCA & $<10 \mathrm{EU}$ \\
\hline & & KL-6 & $286 \mathrm{U} / \mathrm{ml}$ & MPO-ANCA & $<10 \mathrm{EU}$ \\
\hline & & SP-D & $89.4 \mathrm{ng} / \mathrm{ml}$ & Anti-CLIgG Ab & $<8 \mathrm{U} / \mathrm{ml}$ \\
\hline & & & & LA & 1.11 \\
\hline
\end{tabular}


隔の扁平化を認めた（図 1)。胸部 CT 検査では間 質性肺炎所見なく，肺血流シンチでは欠損像を認め なかった。呼吸機能検查では肺活量は正常だが， 拡散能低下（\%DLCO 37.4\%）を認めた（表 2). 右心カテーテル検查で平均肺動脈圧 $59 \mathrm{mmHg}$, 肺

1)

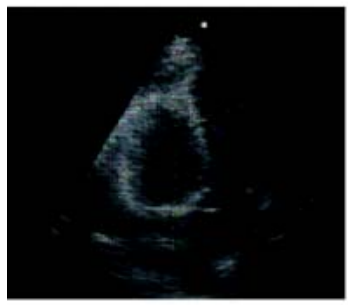

2)
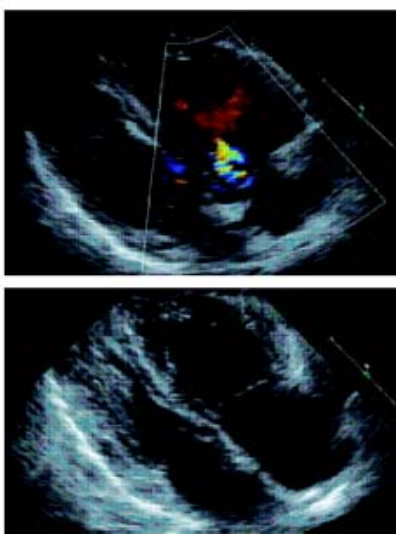

図 1 診断時と $\mathrm{PAH}$ 発症時の心臓超音波検査

1）心房心室サイズ正常, 駆出率 $62 \%$, 三尖弁逆流なし

2）右心房・右心室の拡大あり，右心系による圧排のため心 室中隔の扁平化あり，駆出率 $72 \%$ ，三尖弁逆流 $\mathrm{II}^{\circ}$ ，三 尖弁圧格差 $79 \mathrm{mmHg}$
血管抵抗 $2244 \mathrm{dyne} \cdot \mathrm{sec} \cdot \mathrm{cm}^{-5}$ と著明な上昇を認 め，肺動脈楔入圧の上昇はなかった． 6 分間歩行は $275 \mathrm{~m}$ であった。 また，下肢動脈造影では腓骨動脈 の久開存し，前後脛骨動脈は狭窄・閉塞していた。

臨床経過（図 2）: 肺高血圧症の原因としては強 皮症診断時駆出率低下を認めていたが，肺高血圧症 診断時には正常值を示して抢り，肺動脈楔入圧も正 常で左心不全に伴うもの，間質性肺炎や閉塞性肺疾 患などの肺疾患や低酸素血症に伴うもの，慢性血栓 塞栓に伴うものはいずれも否定的であり，SScに伴 う PAH (SSc-PAH), WHO 肺高血圧症機能分類 3 度と診断した。4 月 20 日よりボセンタン・ベラプ

表 2 診断時と PAH 発症時の呼吸機能検査結果

\begin{tabular}{lcc}
\hline \hline & 診断時 & PAH 発症時 \\
\hline$\% \mathrm{VC}(\%)$ & 93.7 & 104.2 \\
Dlco $(\%) / \mathrm{VA}$ & 40.2 & 37.4 \\
$\% \mathrm{VC} / \%$ Dlco & 2.6 & 2.6 \\
\hline
\end{tabular}

VC : volume capacity

Dlco : Diffusing capacity of the lung for carbon monoxide VA : alveolar ventilation

診断時より SSc-PH を示唆する所見を認めていた。
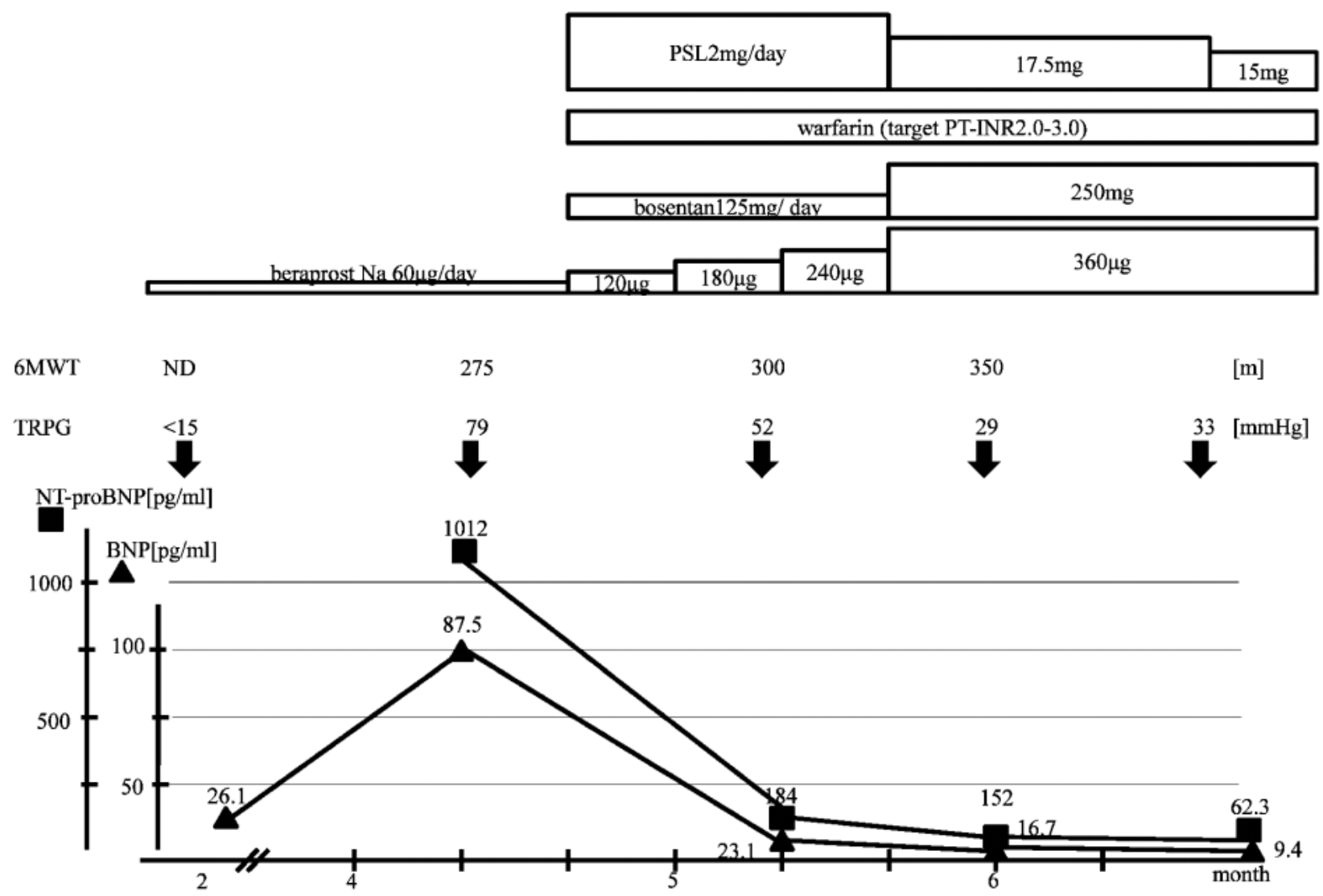

図 2 臨床経過

PSL : prednisolone

6MWT : 6 minutes walking test

TRPG : tricuspid regurgitation pressure gradient 
ロストナトリウム・ワーファリン・プレドニゾロン $20 \mathrm{mg}$ / 日の内服療法を開始した。労作時の呼吸症 状は速やかに改善し, 胸部レントゲン写真上 CTR 48\% と改善, また心臓超音波検査で三尖弁圧較差も 著明に改善し，BNP 值，NTproBNP 值も低下， 2 か月目には正常化した. しかし，その後プレドニゾ ロン漸减に伴い，心臓超音波検査で三尖弁圧較差の 漸増がみられており，今後も慎重な経過観察が必要 な状態である。

\section{考察}

SSc は皮膚の線維性硬化，末梢循環障害を主病変 とする全身性自己免疫疾患である，そのうち全身の 皮膚硬化抒よび内臓臓器病変の合併を併う diffuse cutaneous type (dcSSc) と皮膚硬化が肘または膝を 超えない遠位部に存在し内臓蔵器病変の合併が少な い limited cutaneous type (IcSSc) に大別される1). 主病変である血管病変はレイノー現象や手指・足趾 への虚血から生じる潰瘍, 壊疽など全身の微小・小 血管の障害（microvascular disease）によるものが 多いが，中・大血管の障害 (macrovascular disease) により下肢の循環障害なども引き起こすとされる. 比較的予後良好な $\operatorname{lcSSc}$ においても長期罹病期間の 後に macrovascular disease を合併することが報告 されている2). また，近年心肺病変による死亡率が 増加して抢り, SSc に抢ける心病変の合併は予後不 良因子の 1 つで生命予後を考える意味でも重要な病 態である ${ }^{3)}$. 本症例は SSc 診断後, 2 か月で急速に 進行した PAH を合併し，ステロイド剤を含む多剤 併用治療に速やかに反応した. SSc 診断当初, 心臓 超音波検査では三尖弁逆流や圧較差上昇を認めず， PH の診断には至っていない. しかし, 呼吸機能検 查による PH 評価では肺活量低下に比し, 拡散能 低下が著しいこと（\% VC/\% Dlco > 1.4〜 1.8）が $\mathrm{PH}$ の徵候を示すと報告されており, 本症例も潜在 的に PH 状態を呈していた可能性がある4). また, 足趾潰瘍の存在は macrovascular disease によるも のと考えられ，SSc に長期罹病していた結果と考え られる，そのため，本症例は慢性 PAH の急性増悪 であった可能性が高い.

急性 PAH は急性発症, 慢性 PAH の急性増悪と 手術に起因するもののいずれかの形式をとるとされ $ろ^{5)}$. その機序としては塞栓症, 急性肺損傷, 急性 呼吸窮迫症候群, 敗血症などが挙げられる。しか し，本症例ではその何れも満たさなかった。 また，
SSc-PAH で肺高血圧が急速に進行した報告は文献 検索の範囲では認められなかった。

リウマチ性疾患の抢ける $\mathrm{PAH}$ の危険因子として は lcSSc, 高齢発症 SSc, Raynaud 症状, 多数の毛 細血管拡張, 抗 U1-RNP 抗体陽性, 抗-U3RNP 抗 体陽性, 抗 Ro/SS-A 抗体陽性, 抗 centromere 抗体 陽性, 抗-Th/To 抗体陽性, 抗-B23 抗体陽性, 拡 散能低下 $(\mathrm{DLCO}<55 \%)$ ，爪床毛細血管異常など があげられている6). 一方, macrovascular disease の病因として炎症・血管内皮機能障害とともに自己 抗体の関与が示唆されており, 切断を要する重度の 虚血を有する例では抗 centromere 抗体陽性率が高 く，その関連性が報告されている7)。本症例では PAH の危険因子を多数有しており, 中でも抗 centromere 抗体が陽性であり, macrovascular disease の関連因子でもあることも考慮すると今回足指潰瘍 が悪化していたことと PAH 進行とにも関連がある かもしれないが，その証明はできていない．SScPAH では全身性エリテマトーデスや混合性結合組 織病に比し, 免疫抑制療法への反応に乏しいとされ ている8)．そのため各疾患の重複症状があり，それ らの活動性がある場合にはステロイド剤や免疫抑制 剂効果が期待できるとされるが，SSc-PAH 自体に は推奨されていない9,10). SSc-PAH の病理变化は炎 症所見を伴わない血管内膜の肥厚であることが確認 されており，血管炎でないことが，免疫抑制剂への 反応が得られない理由と考えられている，本症例で は重複症状は認めなかったものの急速に進行した点 を考慮し，ステロイド治療を行った。他の PH 治 療薬を併用して抢り，ステロイド自体の効果の判定 は困難である。しかし，一般的に SSc-PAH では PH 治療でも予後が悪いとされるにも関わらず，本 症例は治療に速やかに反応して抢り，急速に進行し た経過も加味すると血管内膜の肥厚だけでなく， ス テロイド治療に反応するような血管炎などが存在し た可能性が考えられ，更にステロイド減量に伴う心 臓超音波検査で三尖弁圧較差上昇もそれを示唆して いる可能性があると考えている.

本症例の経過より心臓超音波検査上 PH の所見 を認めなくても危険因子を有する症例では PH 存 在の可能性や，また急速な進行を来す可能性がある ことにも注意を要すると考えられた。 


\section{文献}

1) Le Roy EC, et al. : Scleroderma (systemicsclerosis) : classification, subsets and pathogenesis. J. Rheumatol. 15 : 202-205, 1988.

2) Marvi U, et al. : Digital ischemic loss in systemic sclerosis. Int. J. Rheumatol. 2010.pii 130717.

3) Steen VD, et al. : Changes in causes of death in systemic sclerosis, 1972-2002. Ann Rheum Dis. 66 : 940-944, 2007.

4) Steen VD, et al. : Isolated diffusing capacity reduction in systemic sclerosis. Arthritis Rheum 35 : 765-770, 1992.

5) Gan Hui-li, et al. : The Management of Acute Pulmonary Arterial Hypertension. Cardiovasc Ther. 29(3) : 153-175, 2011.

6) Fagan KA, et al. : Pulmonary hypertension associated with connective tissue disease. Prog
Cardiovasc Dis. 45(3) : 225-234, 2002.

7) Park $\mathrm{JH}$, et al. ; Ulnar artery vasculopathy in systemic sclerosis. Rheumatol. Int. 29 : 1081, 2009.

8) C. Opitz, et al. : systemic sclerosis-A systemic overview Part 2-Immunosuppression, treatment of SSc-associated vasculopathy, and treatment of pulmonary arterial hypertension. vasa 40 : 20-30, 2011

9) Jais $\mathrm{X}$, et al. : Immunosuppressive therapy in lupus and mixed connective tissue diseaseassociated pulmonary arterial hypertension : a retrospective analysis of twenty-three cases. Arthritis Rheum 58 : 521-531, 2008.

10) Sanchez O, et al. : Immunosuppressive therapy in connective tissue diseases-associated pulmonary arterial hypertension. Chest 13 : 182-189, 2006. 